\title{
The Molecular Relatedness of $\mathbf{R}$ Factors in Enterobacteria of Human and Animal Origin
}

\author{
By E. S. ANDERSON, G. O. HUMPHREYS \\ AND GERALDINE A. WILLSHAW \\ Enteric Reference Laboratory, Central Public Health Laboratory, \\ London $\mathrm{NW}_{9}{ }_{5} \mathrm{HT}$
}

(Received 2I May 1975)

SUMMARY

The molecular length and DNA homology of R factors isolated from enterobacteria of human and animal origin have been examined. DNA from plasmids of the same compatibility group, whether of human or animal origin, is indistinguishable, after allowance has been made for the regions coding for different antibiotic resistances. These results indicate that there is a common pool of $\mathbf{R}$ factors in man and animals.

\section{INTRODUCTION}

Although it has long been postulated that $\mathrm{R}$ factors in man could be of animal origin (Anderson \& Lewis, I965a,b; Anderson, I $968 a, b$ ), this has been disputed (see, for example, Walton, 1966, I970, 1975; Smith, 1969). Despite the similarity of many R factors identified in enterobacteria isolated from man and animals, no systematic scrutiny of such $\mathbf{R}$ factors has been carried out with the object of establishing the precise degrees of their genetic and molecular relatedness. The identification of several compatibility groups of $\mathrm{R}$ factors (Datta \& Hedges, I97I ; Hedges \& Datta, I97I; Grindley, Grindley \& Anderson, 1972; Smith, Humphreys \& Anderson, I974) and the establishment of the general rule that plasmids belonging to the same compatibility group have close molecular similarity (Guerry \& Falkow, 1971 ; Grindley, Humphreys \& Anderson, 1973) provided methods for determining the precise degree to which $\mathbf{R}$ factors (and other bacterial plasmids) of human origin are related to those found in animals. If the groups identified were the same in all species, they had a common origin; if they were dissimilar, they could have arisen independently in man on the one hand and in animals on the other.

\section{METHODS}

The plasmids investigated, and their sources, are shown in Table I.

All the plasmids examined, code for drug resistance, with the exception of the $\triangle$ transfer factor of which the identified markers are its own transferability, the mobilization of resisttance determinants, its $\mathrm{fi}^{-}$and I-like nature, and the property of phage restriction in salmonellae and Escherichia coli KI2 (Anderson \& Lewis, 1965b; Anderson, 1966, I968b). They belong to compatibility groups already studied genetically by Grindley et al. (1972), and in terms of DNA molecular homology by Grindley et al. (1973). Each group contained at least one factor of human and one of animal origin.

Seven of the 14 factors were apparently acquired by their carrier strains in England. The remaining seven were from widely separated geographical regions, although three of the 


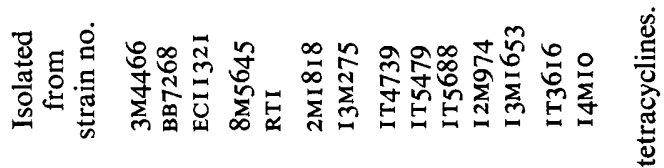

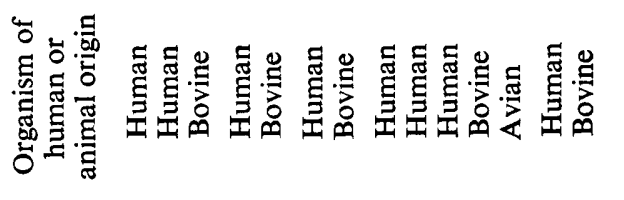

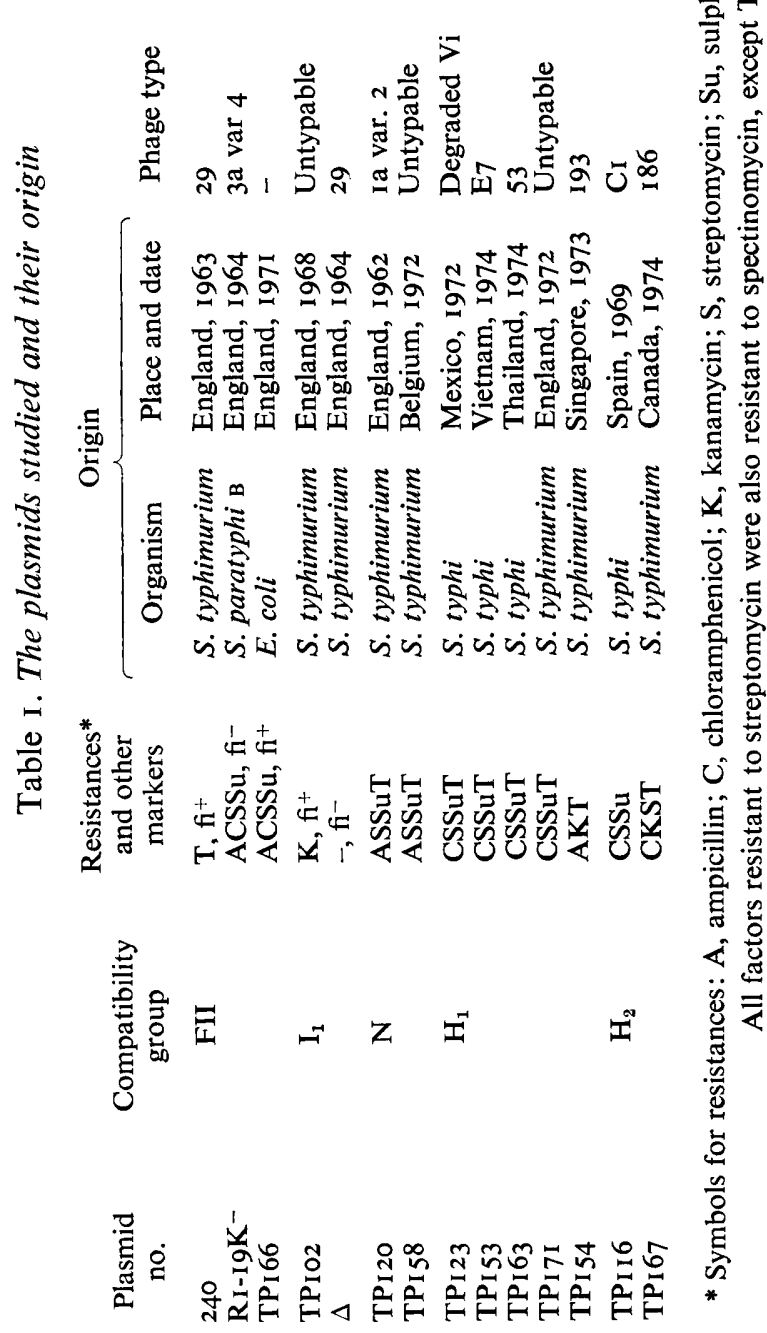


Table 2. Contour lengths and molecular weights of the plasmids

\begin{tabular}{|c|c|c|c|c|c|}
\hline \multicolumn{2}{|l|}{ Plasmid } & \multirow{2}{*}{$\begin{array}{c}\text { Isolated from } \\
\text { strain of } \\
\text { human }(\mathrm{H}) \text { or } \\
\text { animal (A) origin }\end{array}$} & \multirow{2}{*}{$\begin{array}{l}\text { No. of } \\
\text { molecules } \\
\text { measured }\end{array}$} & \multirow{2}{*}{$\begin{array}{c}\text { Mean contour } \\
\text { length } \pm \text { S.D. } \\
(\mu \mathrm{m})\end{array}$} & \multirow{2}{*}{$\begin{array}{c}10^{-6} \times \text { Molecular weight } \\
\text { (daltons) }\end{array}$} \\
\hline $\begin{array}{l}\text { Compatibility } \\
\text { group }\end{array}$ & No. & & & & \\
\hline FII & $\begin{array}{l}240 \\
\text { RI-I9K- } \\
\text { TPI66 }\end{array}$ & $\begin{array}{l}\mathbf{H} \\
\mathbf{H} \\
\mathbf{A}\end{array}$ & $\begin{array}{l}13 \\
15 \\
10\end{array}$ & $\begin{array}{l}19 \cdot 8 \pm 0.3 \\
26 \cdot 2 \pm 0.5 \\
26 \cdot 7 \pm 0.6\end{array}$ & $\begin{array}{l}41 \cdot 0 \\
54 \cdot 2 \\
55 \cdot 3\end{array}$ \\
\hline $\mathrm{I}_{1}$ & $\underset{\Delta}{\mathrm{TPIO}}$ & $\begin{array}{l}\mathbf{H} \\
\mathbf{A}\end{array}$ & $\begin{array}{l}15 \\
30\end{array}$ & $\begin{array}{l}28 \cdot 5 \pm 0 \cdot 6 \\
28 \cdot 7 \pm 0 \cdot 5\end{array}$ & $\begin{array}{l}59 \cdot 0 \\
59 \cdot 4\end{array}$ \\
\hline $\mathbf{N}$ & $\begin{array}{l}\text { TP1 } 20 \\
\text { TPI } 58\end{array}$ & $\begin{array}{l}\mathrm{H} \\
\mathrm{A}\end{array}$ & $\begin{array}{l}\text { I I } \\
\text { I } 2\end{array}$ & $\begin{array}{l}15 \cdot 3 \pm 0.2 \\
17 \cdot 4 \pm 0 \cdot 2\end{array}$ & $\begin{array}{l}3 I \cdot 7 \\
36 \cdot I\end{array}$ \\
\hline $\mathrm{H}_{1}$ & $\begin{array}{l}\text { TPI23 } \\
\text { TPI53 } \\
\text { TPI63 } \\
\text { TPI7I } \\
\text { TPI54 }\end{array}$ & $\begin{array}{l}\mathbf{H} \\
\mathrm{H} \\
\mathbf{H} \\
\mathrm{A} \\
\mathrm{A}\end{array}$ & $\begin{array}{l}12 \\
10 \\
10 \\
12 \\
10\end{array}$ & $\begin{array}{l}59 \cdot 5 \pm 0.8 \\
55 \cdot 2 \pm 1 \cdot 6 \\
55 \cdot 5 \pm 2 \cdot 3 \\
58 \cdot 5 \pm 0.7 \\
61 \cdot 3 \pm 3 \cdot 3\end{array}$ & $\begin{array}{l}\text { I } 23 \cdot 2 \\
\text { I } 14 \cdot 3 \\
\text { I I } 4 \cdot 9 \\
\text { I } 21 \cdot 1 \\
\text { I } 26 \cdot 9\end{array}$ \\
\hline $\mathrm{H}_{2}$ & $\begin{array}{l}\text { TPII6 } \\
\text { TPI67 }\end{array}$ & $\begin{array}{l}\mathbf{H} \\
\mathbf{A}\end{array}$ & $\begin{array}{l}19 \\
10\end{array}$ & $\begin{array}{l}69 \cdot 4 \pm I \cdot 5 \\
82 \cdot 2 \pm 3 \cdot 7\end{array}$ & $\begin{array}{l}143.7 \\
170.2\end{array}$ \\
\hline
\end{tabular}

five $H_{1}$ factors came from salmonellae isolated in South East Asia (Anderson, 1975). The carrier strains were identified between 1962 and 1974 .

The mutual incompatibility of plasmids within each group, and their compatibility with those of other groups, were established by the techniques of Grindley et al. (1972). The molecular properties and relationships were determined by the methods of Grindley et al. (1973). The standard carrier strain was $\mathrm{KI}_{2} \mathrm{~F}^{-}$strain 703 , or its nalidixic acid-resistant mutant I4R525.

\section{RESULTS}

\section{Molecular size of the plasmids}

Table 2 presents the contour lengths of the plasmids as determined by electron microscopy, and the calculated molecular weights. The molecular sizes of members of each group are of the same order, and the factors of human and animal origin in each group conform generally to the characteristic group size. The only possible exception to this was TPI67, an $\mathrm{H}_{2}$ factor from a strain of bovine $S$. typhimurium isolated in Canada. This factor was considerably larger than TPII6, the only other $\mathrm{H}_{2}$ representative studied, but its order of magnitude was closer to TPII6 than to any of the factors of other groups. The $\mathrm{H}_{2}$ plasmids are among the largest so far described.

The difference between the contour length of plasmid 240 ( $\mathrm{T}$ resistance) and those of RI-I9K $\mathrm{K}^{-}$and TPI66 (ACSSu resistance) is probably caused by the presence of the ACSSu linkage group in the latter two plasmids. Dissociation of the ACSSu region from the complete RI-I9K ${ }^{-}$plasmid in $S$. typhimurium and $E$. coli reduces the length of the plasmid by $7 \mu \mathrm{m}$ to about $19 \mu \mathrm{m}$ (Cohen \& Miller. 1969; Humphreys, Willshaw and Anderson, unpublished).

\section{$D N A$ reassociation studies}

The results shown in Table 3 and Fig. I establish clearly the close relationship between the DNA of plasmids of each compatibility group: the homology was always more than $50 \%$, and usually much higher. In contrast, little homology was evident with plasmids of 


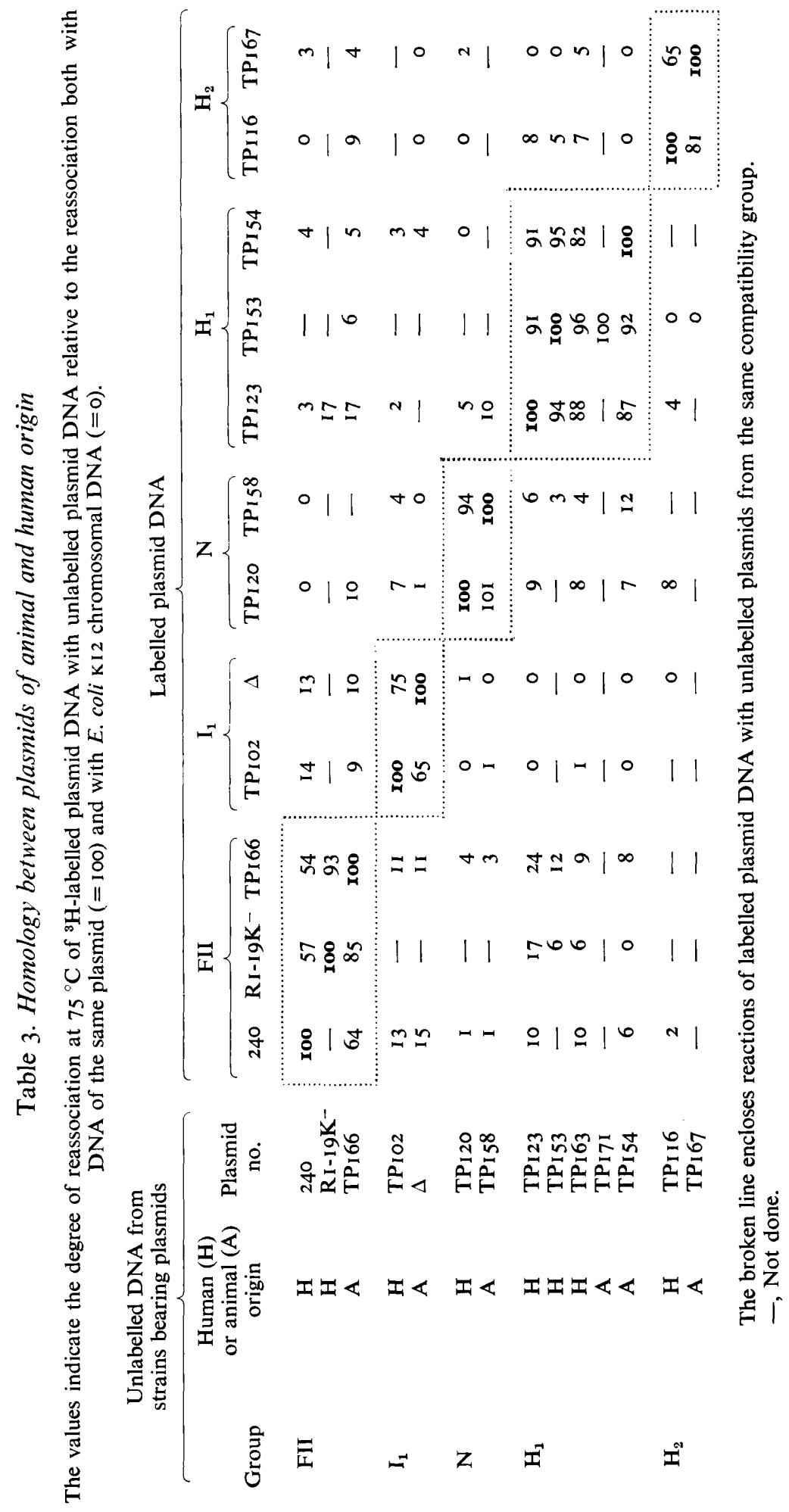



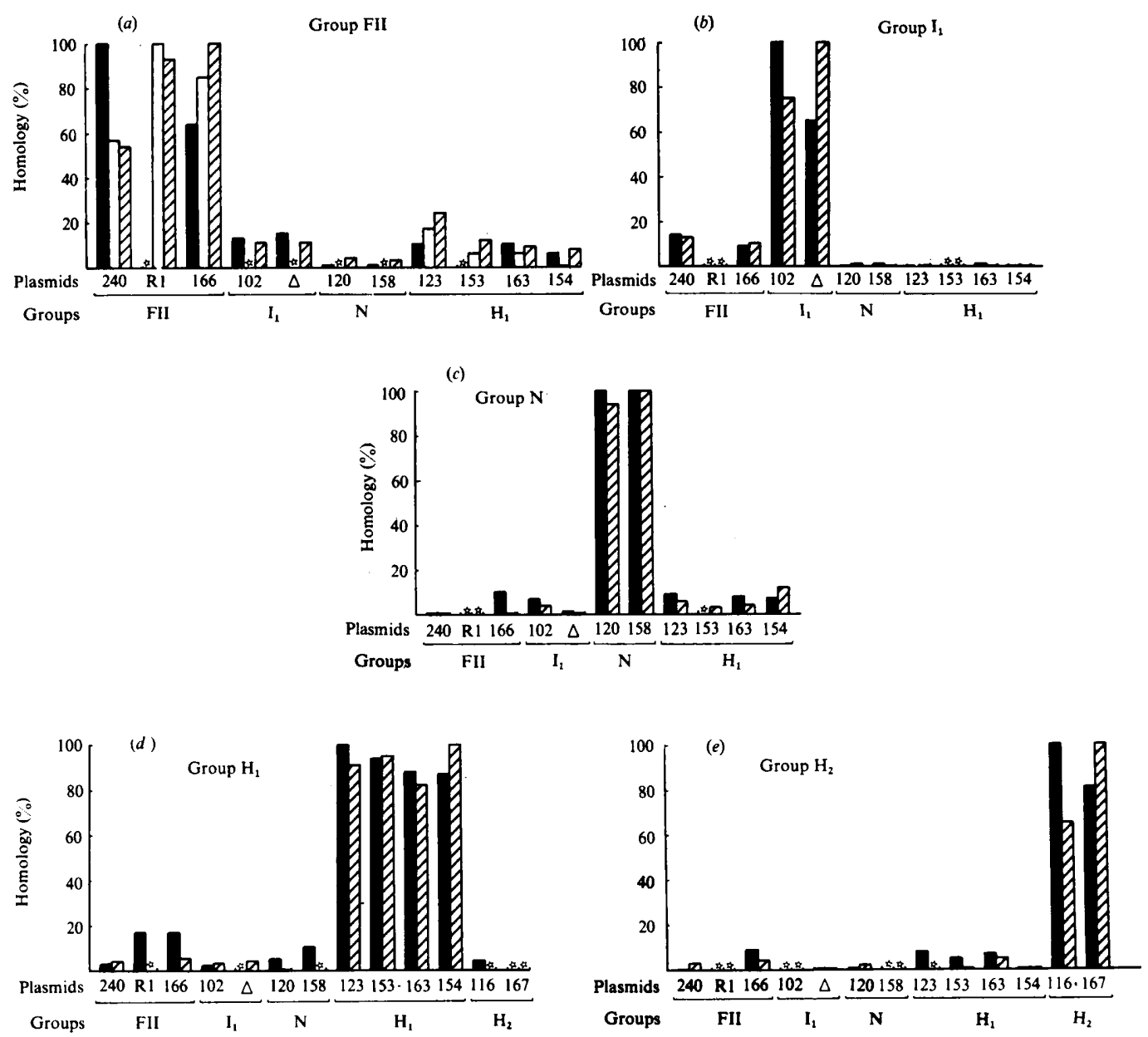

Fig. I. Histograms illustrating the results in Table 3. The findings with each labelled plasmid DNA are plotted individually and divided into compatibility groups as follows. (a) Labelled DNA from the group FII plasmids: $\square, 240$ (human origin); $\square, R_{I}-19 K^{-}$(human origin); $\square$, TPI66 (animal). (b) Labelled DNA from the group $I_{1}$ plasmids: $\square$, TPro2 (human); $\mathbb{Z}, \Delta$ (animal). (c) Labelled DNA from the group $\mathbf{N}$ plasmids: $\mathbf{\square}$, TPI20 (human); $\mathbb{Q}$, TPI58 (animal). (d) Labelled DNA from the group $H_{1}$ plasmids: ${ }$, TPI23 (human); $\$$, TPI54 (animal). (e) Labelled DNA from the group $\mathrm{H}_{2}$ plasmids: $\square$, TPı 6 (human); $\square$, TPI67 (animal). Experiments not done are indicated by a star.

heterologous groups, although figures in excess of about $10 \%$, as found between the FII group with $\mathrm{I}_{1}$ and $\mathrm{H}_{1}$ plasmids, may indicate minor degrees of genetic similarity, either in regions determining antibiotic resistance or in other, unidentified, regions. The outstanding feature of these studies, however, was the close correspondence between the nucleotide sequences of the plasmids of human and of animal origin in each compatibility group. 


\section{DISCUSSION}

The high degree of DNA homology between the auto-transferable plasmids isolated from the enterobacteria of man and of animals establishes unequivocally that in all important respects these plasmids are identical. It can therefore be concluded that they are drawn from a common pool. Differences in genetic markers, such as those for drug resistance, between members of the same group do not affect this argument, because the resistance determinants emerge in response to pressure by a range of antibiotics. Although they recombine with the respective transfer factors to form $\mathrm{R}$ factors, they are of independent origin and may indeed represent the only disparity between the DNA of members of a given compatibility group. Moreover, the same resistances are found in man as in animals, in members of each plasmid compatibility group.

The question that naturally arises is: which is the direction of flow of $\mathrm{R}$ factors and other plasmids - from animals to man or vice versa? Man must contribute to the plasmids of animals, but the opportunity for flow in the opposite direction is probably much greater, bearing in mind the environmental contamination with animal enterobacteria which results from poor food hygiene, the handling of uncooked meat, and the consumption of inadequately cooked meat products. The continuous occurrence of outbreaks of salmonella food poisoning, in which the salmonellae concerned frequently carry $\mathrm{R}$ factors they are known to have acquired in animals, suggests that the animal contribution may be substantial (Anderson \& Lewis, 1965a, $b$; Anderson, $1968 a, b)$. However, these are special cases, and the extent to which animals are a source of $\mathrm{R}$ factors in man cannot easily be determined. Unless plasmid-bearing non-pathogenic enterobacteria such as $E$. coli, of animal origin, can be identified with certainty in man, this problem may remain largely unsolved, since enterobacteria of animal origin, which do not establish themselves in the human intestine, may nevertheless transfer their plasmids to the resident human enterobacteria before disappearing (Anderson, 1968c).

A drastic cutback in the use of antibacterial drugs would probably result in a reduction in the size of the reservoir of resistance plasmids. But $E$. coli carrying $\mathrm{R}$ factors are present and apparently stable in many persons who have never been treated with antibiotics (Anderson, Gillespie \& Richmond, I973; E. S. Anderson, unpublished). This indicates that once some $\mathrm{R}$ factors, from either animal or human sources have gained entry to the enterobacterial population, maintenance of antibiotic pressure is unnecessary for their persistence. Whether total cessation of the use of antibacterial drugs would ultimately result in a massive reduction in the distribution of these plasmids is an unanswerable question, because such cessation cannot be achieved. Indeed, even partial withdrawal is unlikely, though a temporary local withdrawal of the type described by Price \& Sleigh (I970) and Lowbury, Babb \& Roe (1972) can be an effective solution to problems of hospital infection with drug-resistant opportunist pathogens in individual units or areas. Continuous international monitoring of the distribution of $\mathbf{R}$ factors and other plasmids in man and animals is necessary, so that information on this vitally important aspect of human and animal ecology is constantly available.

We thank H. R. Smith, M. M. McConnell and E. J. Threlfall for the genetic characterization of plasmids. 


\section{REFERENCES}

ANDERSON, E. S. (1966). Influence of the $\Delta$ transfer factor on the phage sensitivity of salmonellae. Nature, London 212, 795-799.

ANDERSON, E. S. (I968a). Drug resistance in Salmonella typhimurium and its implications. British Medical Journal iii, 333-339.

Anderson, E. S. (I968b). The ecology of transferable drug resistance in the enterobacteria. Annual Review of Microbiology 22, 13I-I80.

ANDERSON, E. S. (1968c). Transferable antibiotic resistance. British Medical Journal i, 574-575.

ANDERSON, E. S. (1975). The problem and implications of chloramphenicol resistance in the typhoid bacillus. Journal of Hygiene 74, I-II.

Anderson, E. S. \& LeWIS, M. J. (1965a). Drug resistance and its transfer in Salmonella typhimurium. Nature, London 206, 579-583.

ANDERSON, E. S. \& LewIS, M. J. (1965 $b$ ). Characterisation of a transfer factor associated with drug resistance in Salmonella typhimurium. Nature, London 208, 843-849.

Anderson, J. D., Gillespie, W. A. \& Richmond, M. H. (1973). Chemotherapy and antibiotic-resistance transfer between enterobacteria in the human gastro-intestinal tract. Journal of Medical Microbiology 6, 46I-473.

CoHen, S. N. \& MiLler, C. A. (1969). Multiple molecular species of circular R-factor DNA isolated from Escherichia coli. Nature, London 224, I273-1 277.

Datta, N. \& Hedges, R. W. (197I). Compatibility groups among $f^{-}$R factors. Nature, London 234, 222-223.

Grindley, N. D. F., Grindley, J. N. \& ANDERSON, E. S. (1972). R factor compatibility groups. Molecular and General Genetics 119, 287-297.

Grindley, N. D. F., Humphreys, G. O. \& ANDERson, E. S. (1973). Molecular studies of R factor compatibility groups. Journal of Bacteriology 115, 387-398.

Guerry, P. \& FalKow, S. (197I). Polynucleotide sequence relationships among some bacterial plasmids. Journal of Bacteriology 107, 372-374.

Hedges, R. W. \& Datta, N. (197I). $f$-R factors giving chloramphenicol resistance. Nature, London 234, 220-22I.

LANG, D. (I970). Molecular weights of coliphages and coliphage DNA. III. Contour length and molecular weight of DNA from bacteriophages $\mathrm{T}_{4}, \mathrm{~T}_{5}$ and $\mathrm{T}_{7}$, and from bovine papilloma virus. Journal of Molecular Biology 54, 557-565.

LoWBURY, E. J. L., BABB, J. R. \& RoE, E. (1972). Clearance from a hospital of Gram-negative bacilli that transfer carbenicillin-resistance to Pseudomonas aeruginosa. Lancet ii, 94I-945.

Price, D. J. E. \& SLeIGH, J. D. (1970). Control of infection due to Klebsiella aerogenes in a neurosurgical unit by withdrawal of all antibiotics. Lancet ii, 1213-1215.

Smith, H. R., Humphreys, G. O. \& ANDERSON, E. S. (1974). Genetic and molecular characterisation of some non-transferring plasmids. Molecular and General Genetics 129, 229-242.

SмIтH, H. W. (1969). Transfer of antibiotic resistance from animal and human strains of Escherichia coli to resident $E$. coli in the alimentary tract of man. Lancet i, $1174-1176$.

WaLton, J. R. (1966). Infectious drug resistance in Escherichia coli isolated from healthy farm animals. Lancet ii, 1300-1302.

WaLTON, J. R. (1970). Contamination of meat carcasses by antibiotic resistant coliform bacteria. Lancet ii, 56I-563.

WALTON, J. R. (1975). Indirect consequences of low-level use of antimicrobial agents in animal feeds. Federation Proceedings 34, 205-208. 